\title{
Kolektívne práva a povinnosti poddaných Zvolenského panstva (listiny L'udovíta I. a Žigmunda a ich konfirmácie)
}

\author{
PAVOL MALINIAK \\ Katedra histórie, Filozofická fakulta, Univerzita Mateja Bela \\ v Banskej Bystrici
}

Group rights and obligations of subjects of the Zvolen estate (charters issued by Louis I. and Sigismund and their confirmations)

Abstract: In the seat of the Austrian State Archives in Vienna, a simple transcription of medieval charters had been preserved in the material from 1543 in a fund traditionally called Hungarica. The series of charters brings new knowledge about the legal, economic and social status of the subjects of the royal estate in Zvolen. To our knowledge, the charters had not yet been known. The Hungarian king Louis I. of Anjou issued the oldest one in 1360. He had exempted gamekeepers from the villages of Badín, Hájniky and Rybáre (part of the village of Sliač nowadays) from paying the lucrum camerae tax. In 1410, king Sigismund of Luxembourg issued another charter at the request of subjects from the villages of Badín, Vel'ká Lúka, Rybáre, Hájniky, Kováčová, Tŕnie and Trebula (seclusion near the village of Kováčová). The king had confirmed their freedoms they had been following during the reign of his predecessor Louis I. Moreover, the document had also specified how much the subjects should pay in kind. A true analogy is another charter of king Sigismund, issued in 1410 for the subjects of the adjacent castle Vígl'aš. At the request of the specifically named subjects of the Zvolen castle, both charters from the years 1360 and 1410 were confirmed in 1457 by king Ladislaus the Posthumous and subsequently in 1465 by king Matthias Corvinus. Another charters from the years 1457 and 1465 created a parallel to them, addressed by kings to the subjects as freemen from the villages of Hájniky and Rybáre. The last document is a transcription (transumpt) of the charter of Matthias Corvinus. The transcription was issued in 1543 at the request of subjects from the monastery in Hronský Beňadik. All charters stated above are published unabridged and provide suggestions for further research.

Keywords: rights and obligations of subjects, royal gamekeepers, castle estate of Zvolen, transcriptions of medieval charters.

DOI: https://doi.org/10.24040/ahn.2020.23.02.87-104

Sociálne a právne postavenie poddaných na stredovekých hradných panstvách vo väčšine prípadov pramene približujú len nepriamo, bez osobitne zameraných písomností. 0 to väčšiu poznávaciu hodnotu preto nadobúda súbor dokumentov, ktoré v krátkom časovom slede usta- 
novujú a d’alej upravujú vzt'ah vidieckeho obyvatel'stva voči zemepanskej vrchnosti na základnej i rozšírenej úrovni. V sídle Rakúskeho štátneho archívu vo Viedni, vo fonde Uhorské aktá (vecná skupina Všeobecné aktá), nazývanom skrátene Hungarica, sú uložené početné, ale pomerne málo známe dokumenty zo začiatku novoveku s dôrazom najmä na majetkové a administratívne pomery na územiach podliehajúcich korune. Sporadicky sa medzi nimi nachádzajú aj odpisy stredovekých listín. V konkrétnom prípade ide o listiny určené pre poddaných Zvolenského panstva vydávané a potvrdzované jeho vlastníkmi, uhorskými král'mi. V materiáli z roku 1543 je zaradený neoverený odpis tranzumptu vydaného hodnoverným miestom v Hronskom Beňadiku 22. júna 1543 na žiadost' poddaných z dedín Rybáre a Hájniky (dnes obe súčast' mesta Sliač). Text vyhotovený jednou pisárskou rukou na niekol'kých foliách tvorí husto popísaná, ale úhl’adná humanistická kurzíva asi z polovice 16. storočia, ktorá môže datovat' dokument priamo do roku 1543. Tranzumpt obsahuje listinu vydanú Matejom Korvínom 24. marca 1465, ktorou konfirmoval listinu vydanú Ladislavom Pohrobkom 7. apríla 1457. Aj v prípade Ladislava Pohrobka ide o konfirmáciu potvrdzujúcu dve staršie listiny - Žigmunda Luxemburského z 1. mája 1410 a L’udovíta I. z Anjou z 25. júla $1360 .^{1}$ Ako uvidíme d'alej, listiny sa s vel'kou pravdepodobnost'ou zachovali v plnom znení. Datovanie najstaršej z nich je pritom otázne. Hoci materiál z fondu Hungarica už dlhodobo študujú historici a editori stredovekých prameňov, ${ }^{2}$ podl'a našich vedomostí vyššie uvedené listiny ešte neboli publikované a kriticky zhodnotené.

Dôvody, prečo došlo v roku 1543 k tranzumovaniu a k zaradeniu odpisu medzi Uhorské aktá nepoznáme. Samotný tranzumpt takéto údaje neobsahuje a jeho súčasný odpis nezahŕňa vysvetl'ujúce kancelárske poznámky. Okrem toho, na základe súčasného stavu poznania ide o jediné známe zachovanie uvedeného prameňa. ${ }^{3}$ Vzhl'adom na charakter fondu (v ktorom je bežne zastúpená korešpondencia županov

Táto práca bola podporovaná Agentúrou na podporu výskumu a vývoja na základe Zmluvy č. APVV-17-0063.

1 Österreichisches Staatsarchiv Wien (d’alej ÖStA), Abteilung Haus-, Hof- und Staatsarchiv (d'alej HHStA), Ungarische Akten, Allgemeine Akten, Fasc. 52 (1543. VI-IX.), Konv. A, fol. $49 \mathrm{r}-54 \mathrm{v}$.

${ }^{2}$ Napr. v roku 1889 Smičiklas, 1894 Bunyitay, 1929 Iványi, 1934 Lukinich. ÖStA, HHStA, Ungarische Akten, Allgemeine Akten, Fasc. 52 (1543. VI-IX.), Konv. A, priložené zoznamy bádatel'ov v konvolúte a fascikli.

3 Vo fonde hodnoverného miesta sa koncept ani rovnopis tranzumptu podl'a všetkého nenachádzajú. Porov. Slovenský národný archív v Bratislave (d’alej SNA), fond Hodnoverné miesto Konventu benediktínov v Hronskom Beňadiku, Autentický protokol A (1411 1551), B (1518 - 1549), C (1526 - 1600), ktoré som študoval. V rámci listín v uvedenom fonde o tranzumpte chýba zmienka v mennom indexe k fasc. 1 - 124. Za informáciu d'akujem Marekovi Púčikovi, pracovníkovi SNA. 
Kolektívne práva a pvinností poddaných Zvolenského panstva ...

s panovníckym dvorom) nemožno vylúčit', že odpis tranzumptu medzi Hungarica zabezpečil vtedajší zvolenský župan a zároveň správca Zvolenského panstva. Zvolenským županom a hradným kapitánom bol v rokoch 1542 - 1546 pôvodom český šl'achtic Mikuláš Prusinovský z Víckova. Podliehal uhorskej král'ovnej vdove Márii Habsburskej, ktorej v tom čase patrilo Zvolenské panstvo a d'alšie majetky ako jej vdovské zabezpečenie. ${ }^{4}$

Podl'a zachovaného znenia najstaršiu spomedzi inzerovaných listín vydal král' Ludovít I. vo Zvolene 25. júla 1360. Datovanie otvára d'alšie otázky, lebo podl'a dosial' známych poznatkov pobyt panovníka vo Zvolene v tom čase nebol doložený. ${ }^{5} \mathrm{~V}$ predchádzajúcich i nasledujúcich dňoch L'udovít I. vydával listiny na Vyšehrade (Visegrád), čo však nevylučuje jeho cestu do Zvolena. ${ }^{6} \mathrm{Ak}$ by to tak nebolo, v datovacej formulke nemožno vylúčit' chybu, ktorá mohla vzniknút' pri prepisovaní dokumentu. Podl'a listiny s datovaním 25. júla 1360, král' oslobodil svojich poddaných - bližšie nemenovaných hájnikov z dedín Badín, Hájniky a Rybáre vo Zvolenskej stolici od povinnosti platit' komorský zisk (exactiones seu solutiones pro lucro camere nostre). Vyberačom komorského zisku král' zároveň prikázal, aby ho od poddaných v Badíne, Hájnikoch a Rybároch nevyberali. ${ }^{7}$ Listina je pomerne jednoducho koncipovaná, má však osobitný význam pre dejiny osídlenia, poznanie administratívnych pomerov a zamestnania obyvatel'stva. Vzhl'adom na jej zachovanie v mladšom neoverenom odpise, treba za problematickú považovat' ortografiu. Trojicu sídiel uvádza v tvaroch Badin, Haynyk, Halazekfalwa. V prvom prípade je zápis Badin v listine z vrcholného a rovnako aj z neskorého stredoveku neobvyklý. Sídlo vystupuje v originálnych písomnostiach pod inými označeniami. ${ }^{8}$ Naopak, v prípade sí-

\footnotetext{
${ }^{4}$ MATULAY, Ctibor: Kongregačný protokol Zvolenskej župy z r. 1506 - 1579. In: Historické štúdie XI. 1966, s. 198; KENYERES, István: Verwaltung und Erträge von Königin Marias ungarischen Besitzungen in den Jahren 1522 bis 1548. In: Maria von Ungarn (1505 1558). Eine Renaissancefürstin. Hgg. Martina Fuchs - Orsolya Réthelyi, Münster : Aschendorff Verlag, 2007, s. $202-203$.

5 Príslušný zväzok z edície Anjou-kori oklevéltár XLIV (1360) v súčasnosti pripravuje Ferenc Sebők zo Segedínskej univerzity (Szegedi Tudományegyetem), ktorému d'akujem za informáciu.

${ }^{6}$ Listiny z 22. júla 1360 vydané in Wyssegrad. NAGY, Emericus - NAGY, Johannes Baptista - VÉGHELY, Desiderius (eds.): Codex diplomaticus domus senioris comitum Zichy de Zich et Vasonkeő III. Pestini : Editio Societatis Histor. Hung., 1874, s. 186 - 187, č. 126; Magyar Nemzeti Levéltár Országos Levéltára Budapest (d’alej MNL OL), Diplomatikai levéltár (d'alej DL) 77 283, 41 582, Diplomatikai fényképgyűjtemény (d’alej DF) 244 324. Ďalšie datovanie in Wyssegrad v listine z 1. augusta 1360. MNL OL DL 104926.

${ }^{7}$ Znenie listiny v prílohe č. 1.

8 ĎURKOVÁ, Mária: Vývoj osídlenia Zvolenskej a Pliešovskej kotliny v stredoveku. In: Historický časopis. roč. 44, č. 2, 1996, s. 169; MALINIAK, Pavol: Osídlenie od 13. storočia do konca stredoveku. In: Osídlenie Zvolenskej kotliny od včasného stredoveku do polovice
} 
diel Hájniky a Rybáre sa použité formy zápisov nemuseli príliš odchyl'ovat' od označení používaných počas stredoveku. Relatívne ustálené zápisy typu Haynyk alebo Haynik prevažujú aj v d'alších listinách. ${ }^{9}$ Pestrejšie podoby zapisovania nadobudli susedné Rybáre. Zápis v tvare Halazekfalwa možno rekonštruovat' v mad'arskom znení Halászokfalva. Ako ešte uvidíme pri konfirmáciách pôvodnej listiny, toto označenie vytvorené pisármi mohlo viest' $\mathrm{k}$ súbežnému používaniu dvoch názvov pre rovnaké sídlo.

Listina Ludovíta I. z roku 1360 poskytuje údaj o prítomnosti král’ovských hájnikov, o ktorých v Badíne a Hájnikoch nachádzame doklady už v 13. storočí, avšak z mladšieho obdobia takéto doklady chýbali. Doterajšie bádanie opakovane sústred'ovalo pozornost' predovšetkým na pôvod, počiatky, rozšírenie, organizáciu a pôsobnost' hájnikov a král'ovských lesov s dôrazom na obdobie vlády Arpádovcov. 0 pokračovaní, pretváraní a zániku tejto inštitúcie v mladšom období sa zachovalo menej dokladov, pričom uvedeným témam venovala menšiu pozornost' i historiografia. Najstaršie pramene sa pokúsili prepojit' s dokladmi z neskorého stredoveku najmä László Zolnay a Eszter Magyar. Zretel'nú medzeru napriek tomu nad'alej tvorilo obdobie vlády Anjouovcov. ${ }^{10}$ Listina z roku 1360 preto môže doplnit' odmlku v doposial' skúmanom a známom materiáli. Od starších prameňov $\mathrm{k}$ inštitúcii hájnikov v regióne sa navyše líši tým, že panovník oslobodenie od daní adresoval naraz trom dedinám. Hoci listina to výslovne neuvádza, na základe mladších prameňov vieme, že uvedené dediny patrili pod správu Zvolenského hradu.

19. storočia. ed. Oto Tomeček, Banská Bystrica : Fakulta humanitných vied UMB, 2009, s. 70 - 71. Ďalšie zápisy v tvaroch Bagyon a Bagion porov. MNL OL DF 287 107, 254203.

${ }^{9}$ MALINIAK, P.: Osídlenie od 13. storočia, s. 76.

10 ZOLNAY, László: Vadászatok a régi Magyarországon. Budapest : Natura, 1971, s. 103 104, 113 - 115, 150 - 161, 185 - 195; BOROSY, András: Adatok az udvar- és erdőispánságok történetéhez az Árpád-korban. In: Agrártörténeti Szemle. XIX. évf., 3-4 sz., 1977, s. 328 - 329, 331 - 332; CSŐRE, Pál: A magyar erdőgazdálkodás története. Középkor. Budapest : Akadémiai Kiadó, 1980, s. 139 - 143; MAGYAR, Eszter: A királyi erdőkezelés kiváltságolt népcsoportjainak továbbélése a bakonyi erdőispánság területén. In: Tanulmányok Veszprém megye múltjából. szerk. László Kredics, Veszprém : Kiadja a Veszprém Megyei Levéltár, 1984, s. 104 - 105, 110 - 116; KRISTÓ, Gyula: A vármegyék kialakulása Magyarországon. Budapest : Magvető Könyvkiadó, 1988, s. 377 - 382; ĎURKOVÁ, Mária: Osídlenie historického mikroregiónu Zvolen a inštitúcia custodes silvarum z pohl'adu najstarších písomných prameňov. In: Zvolen 1243 - 2008. Zborník príspevkov z vedeckých konferencií. zost. Júlia Ragačová - Pavol Maliniak, Zvolen : Mesto Zvolen, 2008, s. 105 108; ULIČNÝ, Ferdinand: Dejiny Slovenska v 11. až 13. storočí. Bratislava : Veda, 2013, s. 239 - 240, 246, 253 - 257, 262 - 263; HUDÁČEK, Pavol: Král’ovské lesy a dynastické majetky Arpádovcov v 11. - 12. storočí (Porovnanie so západnou Európou). In: KOVÁČ, Dušan a kol.: Slovenské dejiny v dejinách Európy. Vybrané kapitoly. Bratislava : Veda, 2015, s. $38-66$. 
Kolektívne práva a pvinností poddaných Zvolenského panstva ...

V poradí druhým spomedzi konfirmovaných dokumentov je listina král'a Žigmunda vydaná na Vígl'aši 1. mája 1410. Podl'a publikovaného itinerára sa panovník v tom čase skutočne zdržiaval na hrade Vígl'aš. ${ }^{11}$ Prívlastok Vígl'aša použitý $\mathrm{v}$ datovacej formulke (podl'a príslušnosti k Zvolenskej stolici) uvádza aj iná listina vydaná Žigmundom v rovnaký deň. ${ }^{12}$ Podl'a nami skúmanej listiny nemenovaní král'ovskí poddaní (cives et iobagiones nostri regales) z Badína, Vel'kej Lúky, Rybárov, Hájnikov, Kováčovej, Tŕnia a Trebule predstúpili pred krála Žigmunda a predniesli st'ažnost' na kastelánov a vicekastelánov Zvolenského hradu, ktorému podliehali. Poddaných zat’ažovali neprimeranými daňami, dávkami, službami a používaním väčšej miery. Žigmund preto potvrdil ich slobody, ktorými sa riadili počas vlády jeho predchodcu L'udovíta I. Zároveň určil, aby každý poddanský dvor odvádzal štyri vozy sena, štyri vozy dreva a obilie $v$ takej miere, s akou sa obchoduje na miestnom trhu. Dávky mali každoročne odvádzat' na miestach a v termínoch určených oddávna. Mimoriadne dávky potravín mohli od nich kasteláni alebo vicekasteláni vyžadovat' len vtedy, ak kraj navštívil panovník. Kastelánom, vicekastelánom a ich úradníkom Žigmund prísne nariadil, aby ustanovenia dodržiavali. ${ }^{13}$ Označenie cives, použité popri iobagiones, a následne i populos mohlo $\mathrm{v}$ danom prípade označovat' určitý rozsah práv a slobôd, ktorými poddaní disponovali. Z hl'adiska obsahu a adresátov je zaujímavá d’alšia Žigmundova listina vydaná rovnako 1. mája 1410. Král' ju vydal na žiadost' poddaných zo Zvolenskej Slatiny, Očovej a Zolnej, ktoré podliehali hradu Vígl'aš. Ide o analogický dokument - má rovnaký obsah a len v niektorých častiach odlišnú štylizáciu. ${ }^{14}$ Navonok jednoduché a iba čiastočne spresnené povinnosti v podobe naturálnych dávok časom viedli k úpravám a navyšovaniu. Vidíme to práve v prípade Vígl'ašského panstva, kde po zmene feudálneho vlastníka s niekol'kogeneračným odstupom rozsah povinností poddaných výrazne narástol. ${ }^{15}$ Zvolenské panstvo zostalo nad'alej v král'ovských rukách a zrejme i preto úpravy povinností nepoznáme.

\footnotetext{
${ }^{11}$ ENGEL, Pál - TÓTH, Norbert C.: Itineraria regum et reginarum (1382 - 1438). Subsidia ad historiam medii aevi Hungariae inquirendam 1. Budapest : Kiadja a Magyar Tudományos Akadémia, 2005, s. 91.

12 Datum in castro nostro Wegles Zolyensi. MÁLYUSZ, Elemér (ed.): Zsigmondkori oklevéltár II/2. (d’alej ZsO II/2) Budapest : Akadémiai Kiadó, 1958, s. 349, č. 7537.

13 Znenie listiny v prílohe č. 2 .

${ }_{14}$ ZsO II/2, s. 350, č. 7541. Inzert v konfirmácii Rudolfa I. z roku 1598. MNL OL, A 57, Magyar Kancelláriai Levéltár (d’alej MKL), Libri regii I, pag. 390-391. Pasáž s odchýlkami v ortografii uverejnil WENZEL, Gusztáv: Magyarország mezőgazdaságának története. Budapest: Magyar Tudományos Akadémia, 1887, s. 291.

15 MNL OL DL 63 398; BORSA, Iván (ed.): A Justh család levéltára 1274 - 1525. Budapest : Akadémiai Kiadó, 1991, s. 175 - 176, č. 477. Podrobnejšie formulované povinnosti, zvlášt' odovzdávanie potravín, porov. PACH, Zsigmond P.: The Development of Feudal Rent in
} 
Žigmundova listina vydaná v roku 1410 pre poddaných Zvolenského hradu uvádza sídla, z ktorých pozostávalo hradné panstvo: Badín, Vel'ká Lúka, Rybáre, Hájniky, Kováčová, Tŕnie a Trebula (Badin, Velkeluka, Rybar, Haynyk, Kowacho, Thernye, Treble). V prípade, ak zachovaný odpis odráža formy zápisov podl'a originálnej predlohy, vybočuje z doposial' známych stredovekých dokladov označenie Vel'kej Lúky, ktorej názov pisári zrejme kvôli zrozumitel'nosti obvykle prekladali do mad'arského znenia Nagyrét. ${ }^{16}$ Príslušenstvá Zvolenského panstva podl'a listiny tvorilo sedem sídiel. Zdá sa, že išlo o celé majetky bez podielov. Z roku 1424, ked' král' Žigmund daroval panstvo svojej manželke Barbore Celjskej, pochádza úplnejší zoznam hradných majetkov. Vystupujú v ňom podiely v dedinách Lieskovec a Král'ová, dediny Rybáre, Hájniky, Vel'ká Lúka, Lukavica, Badín s mýtom, Trebul'a, Tŕnie a Môt'ová. ${ }^{17}$ Okrem Lieskovca a Král'ovej vieme, že panstvo vlastnilo podiel aj v Lukavici. Posledné sídlo Môtová malo $\mathrm{v}$ rámci panstva osobitné postavenie, preto zrejme tiež nefigurovalo v súpise z roku 1410. Naopak, prekvapuje, že súpis z roku 1424 nespomína Kováčovú. ${ }^{18}$ Napriek chýbajúcej evidencii majetkových podielov, Žigmundova listina z roku 1410 podl'a súčasného stavu poznania predstavuje najstarší známy súpis Zvolenského panstva. Prispieva tak k spresneniu rozsahu panstva a príslušnosti jednotlivých majetkov k nemu.

Listinu L'udovíta I. z roku 1360 aj Žigmundovu listinu z roku 1410 konfirmoval v roku 1457 král' Ladislav Pohrobok. V Budíne 7. apríla 1457 pred panovníka predstúpili Bartolomej Brazovič - alebo Pražovič - (Brazowyth, Prazowith) z Rybárov a Juraj Bobor so synom Ondrejom z Hájnikov. V mene svojich spoluobyvatel'ov, ako aj v mene ostatných poddaných Zvolenského hradu z Badína, Vel'kej Lúky, Kováčovej, Tŕnia a Trebule požiadali o odpis a potvrdenie vyššie uvedených listín. Druhý zo suplikantov najprv vystupuje v tvare Gregor Bobor, následne Juraj

Hungary in the Fifteenth Century. In: The Economic History Review. Second Series, Vol. XIX, No. 1, 1966, s. 7 - 9; SOKOLOVSKÝ, Leon: Správa stredovekej dediny na Slovensku. Bratislava : Academic Electronic Press, 2002, s. 52 - 55.

16 MALINIAK, P.: Osídlenie od 13. storočia, s. 112 . V roku 1501 poznáme názov len nepriamo, ked' vystupuje zvolenský mešt’an Ondrej Welkyluczky. Štátny archív v Banskej Bystrici (d’alej ŠA BB), pracovisko Archív Zvolen (d'alej p. AZv), fond Magistrát mesta Zvolen (d’alej MMZv), škat. 1, Mestská kniha I, fol. 6r.

${ }^{17}$ portionibus in villis Lyskowch et Kyralfalwa habitis, nec non aliis villis Halazy, Ardo, Nagreth, Lwkocza, Bagyon cum tributo ibidem habito, Trebuya, Themye et Mothfalwa appellatis. MNL OL DF 287 107; NEUMANN, Tibor - TÓTH, Norbert C. (eds.): Zsigmondkori oklevéltár XI. Budapest : Kiadja a Magyar Országos Levéltár, 2009, s. 232, č. 584; WENZEL, Gusztáv (ed.): Okmányi adalék Borbála és Erzsébet magyar királynék birtokáról. In: Magyar történelmi tár XII. 1863, s. 275. K ojedinelému označeniu Hájnikov v podobe Ardo porov. KARÁCSONYI, János: Mit jelent e helynév „Ardó?“. In: Ethnographia. 13. évf., 1902, s. 349; HUDÁČEK, P.: Král'ovské lesy, s. 56, pozn. 116.

${ }^{18}$ MALINIAK, P.: Osídlenie od 13. storočia, s. 81 - 82, 85 - 86, 91 - 92. 
Kolektívne práva a pvinností poddaných Zvolenského panstva ...

Bobor. ${ }^{19}$ Podobu krstného mena spresňuje d’alší prameň. Rovnako v roku 1457, len krátko pred vydaním novej konfirmácie, král' Ladislav Pohrobok vydal na žiadost' Ondreja a Tomáša, synov Juraja Bobora, donáciu na ich usadlost' v Hájnikoch. Podobu mena Juraj Bobor preto možno považovat' za hodnovernejšiu. Donačná listina nijako nespresňuje sociálne postavenie adresátov. Panovníkov mandát adresovaný Turčianskemu konventu nariad'ujúci ich vovedenie do držby za účasti zástupcu Zvolenskej stolice akoby naznačoval ich príslušnost' k zemanom..$^{20}$ Konfirmácia z roku 1457 však Juraja a Ondreja Bobora zarad'uje k poddaným. S prihliadnutím na mladšie pramene vieme, že Boborovci z Hájnikov spočiatku patrili medzi slobodníkov a až po nobilitácii od 16. storočia figurovali medzi zemanmi. ${ }^{21}$

Vo vzt'ahu k použitej ortografii možno upozornit’ na súbežné označovanie dediny Rybáre dvomi názvami. Bydlisko prvého zo žiadatel'ov, Bartolomeja, listina uvádza v mad’arskom tvare Halazekfalwa. Medzi ostatnými sídlami podliehajúcimi Zvolenskému hradu nachádzame opät' Rybáre, ale tentoraz v slovenskom tvare Rybar. Susedné Hájniky sú zapísané pri odkaze na pôvod žiadatel'ov iba vo forme Haynyk. Listina ich preto duplicitne neuvádza. Vzhl'adom na zachovanie prameňa v neskoršom odpise nemožno vyslovit' jednoznačný záver. Môžeme len predpokladat', že pisára ovplyvnili dve rôzne podoby názvu Rybárov zaznamenané v listinách z rokov 1360 a 1410, ktoré nedokázal identifikovat' a zjednotit'. Rovnaký postup pozorujeme aj v konfirmácii z roku 1465.

Zástupcovia poddaných Zvolenského panstva po zmene panovníka znovu predstúpili so žiadost'ou o potvrdenie svojich práv a povinností. Informuje o tom listina vydaná Matejom Korvínom 24. marca 1465. Lokačná formulka v nej nie je uvedená. Pohl’ad do Matejovho itinerára naznačuje, že král' sa vtedy mohol zdržiavat' vo Zvolene, presnejšie na Zvolenskom zámku. ${ }^{22} \mathrm{O}$ vydanie konfirmácie požiadali Pavol Žember a On-

\footnotetext{
${ }^{19}$ Znenie listiny v prílohe č. 3 .

${ }^{20}$ Listina Ladislava Pohrobka vydaná v Budíne 19. marca 1457 sa zachovala v odpise z roku 1771. SNA, špecializované pracovisko Slovenský banský archív v Banskej Štiavnici, fond Komorské panstvo Zvolen - Dobrá Niva, inv. č. 510, nr. 16. K obsahu viac MALINIAK, Pavol: Človek a krajina Zvolenskej kotliny v stredoveku. Banská Bystrica : Fakulta humanitných vied UMB, 2009, s. 115.

${ }^{21}$ MNL OL, P 46, Beniczky család, 1. tétel, 1. csomó, 1564/nr. 10; MNL OL, Magyar Kamara Archívuma (d'alej MKA), E 158, Conscriptiones portarum, Comitatus Zoliensis 1566, pag. 411; ŠA BB, fond Zvolenská župa (d’alej ZŽ), Kongregačný protokol I, pag. 454 - 455; CHERVEN, Flóris: Jelentés Zólyom-megye levéltáráról. In: Századok. IX. évf., 1875, s. 121; FŐGLEIN, Antal: Családtörténeti adatok Zólyom vármegyéből. In: Magyar Családtörténeti Szemle. 10. sz., 1937, s. 71.

22 Pobyt král'a vo Zvolene 26. - 27. marca 1465 dokladá HORVÁTH, Richárd: Itineraria regis Matthiae Corvini et reginae Beatricis de Aragonia (1458 - [1476] - 1490). Budapest : História - MTA Történettudományi Intézete, 2011, s. 78.
} 
drej Kernath z Badína. Spolu s nimi boli žiadatel'mi aj Gregor, syn Matúša, a Bartolomej Psár z Rybárov. Nemožno vylúčit', že prímeno Kernath znelo Kernáč alebo Krnáč, hoci jeho rekonštruovanie (kvôli zachovaniu v odpise) je problematické. ${ }^{23}$ Vzhl'adom na zamestnanie a povinnosti obyvatel'ov je pozoruhodné prímeno Psár. Môže vypovedat' o prítomnosti král'ovských psiarov, ku ktorým patril Bartolomej alebo jeho predkovia (ak prímeno zdedil). Suplikanti z Badína a Rybárov požiadali o odpis a potvrdenie konfirmácie Ladislava Pohrobka z roku 1457. Zároveň predniesli žiadost' aj v mene poddaných z Hájnikov, Vel'kej Lúky, Kováčovej, Tŕnia a Trebule, ktoré podliehali Zvolenskému hradu. ${ }^{24}$ Okrem uvedenej konfirmácie Matej Korvín v rovnaký deň potvrdil i d’alšie písomnosti z regiónu. Král' vydal 24. marca 1465 aj konfirmáciu donačnej listiny král'a L’udovíta I. pre Juraja, syna Mikuláša Kováča, a jeho príbuzných na usadlost' v Rybároch (podobne, ako v prípade Boborovcov, išlo zrejme o slobodníkov). ${ }^{25} \mathrm{~S}$ rovnakou datovacou formulkou a znovu bez uvedenia miesta vydal Matej Korvín aj listinu pre mesto Zvolen, ktorá sa zachovala v origináli. Na žiadost' zástupcov mesta vtedy konfirmoval výsadné listiny vydané Belom IV. a Ladislavom IV. ${ }^{26}$

Celý rukopis, v ktorom sa zachovali inzerované listiny pre poddaných Zvolenského panstva, tvorí tranzumpt hodnoverného miesta v Hronskom Beňadiku. Vydaný bol 22. júna 1543, pričom o tranzumovanie listiny Mateja Korvína z roku 1465 požiadali Juraj Rác a Matej Bál, zástupcovia obcí Rybáre a Hájniky. Ďalšie sídla sa pritom už neobjavujú. ${ }^{27}$ Prvého zo žiadatel'ov následne nachádzame v Rybároch vo funkcii richtára. ${ }^{28}$ Tento údaj podporuje logický záver, že medzi suplikantmi obvykle vystupovali richtári a prísažní z jednotlivých dedín. Druhé prímeno azda znelo Bál alebo Balko, ako to naznačujú mladšie údaje z obidvoch dedín. ${ }^{29}$ Okrem

\footnotetext{
${ }^{23}$ Súpis poddaných Zvolenského panstva z roku 1652 spomína v Badíne obývanú aj pustú usadlost' s prímenom Zember. MNL OL, P 1291, Esterházy család zólyomi ágának levéltára (d’alej Esterházy cs. lt.), Uradalmi iratok, 89 csomó, fol. 24r. Znenie druhého prímena naznačuje údaj z blízkej Kremničky. V roku 1558 tam vystupuje poddaný s prímenom Kernacz. ŠA BB, ZŽ, Kongregačný protokol I, pag. 350.

${ }^{24}$ Znenie listiny v prílohe č. 4.

25 Inzert v konfirmácii Leopolda I. z roku 1692. MNL OL, A 57, MKL, Libri regii XXI, pag. 267 - 268. Odpis obsahuje neúplné vročenie listiny L'udovíta I. vydanej v Slatine (Zalathna) 25. júla 13[...]. J. Illésy listinu bez bližšej argumentácie datoval do roku 1372. ILLÉSSY, János: Községi kiváltságlevelek jegyzéke. Harmadik közlemény. In: Magyar Gazdaságtörténelmi Szemle. 5. évf., 1898, s. 353.

${ }^{26}$ ŠA BB p. AZv, MMZv, Listiny, škat. 2, inv. č. 22.

${ }^{27}$ Znenie listiny v prílohe č. 5 .

${ }^{28}$ Iudex Georgius Racz. MNL OL, MKA, E 158, Conscriptiones portarum, Comitatus Zoliensis 1549, pag. 164.

${ }^{29}$ Súpis poddaných z roku 1652 spomína v Rybároch pustú a v Hájnikoch obývanú usadlost' s prímenom obyvatel'ov Balkouiech. MNL OL, P 1291, Esterházy cs. lt., Urad. iratok, 89 cs., fol. 20r, 22v.
} 
skutočnosti, že tranzumpt zaznamenal predchádzajúce konfirmácie a pôvodne vydané listiny, môže o prebiehajúcich zmenách vypovedat' už len prítomnost' dvoch dedín a ich zástupcov medzi žiadatel'mi a adresátmi.

V rámci obsahovo blízkych prameňov k stredovekým dejinám Zvolenského panstva boli známe a bádatel'mi využívané iba výsady král'ovských hájnikov z Môt’ovej, ktoré v roku 1464 vydal, resp. obnovil Matej Korvín. ${ }^{30} \mathrm{Na}$ rozdiel od tohto prameňa, ktorý bol určený pre komunitu obyvatel'ov jednej obce, kolektívne práva a povinnosti pre poddaných z rokov 1360 a 1410 môžu vo väčšom rozsahu charakterizovat' hospodárske, sociálne i právne pomery takmer na celom Zvolenskom panstve. Napriek problematickej ortografii ovplyvnenej mladším odpisom možno zoznamy sídiel (príslušenstiev) najpravdepodobnejšie považovat' za hodnoverné. Skúmaný súbor prameňov preto umožňuje presnejšie sledovat' rozsah hradného panstva. Dominantné sa pritom javia Badín, Hájniky a Rybáre, ktorým bol určený najstarší z dokumentov. Zástupcovia uvedených troch dedín azda aj z tohto dôvodu opakovane žiadali o odpis a potvrdenie mladších listín. Osobitnú pozornost' bude vyžadovat' obsah ustanovení a formulácie použité v listinách, kde sa môže uplatnit' porovnávací výskum. Napokon, výpovednú hodnotu majú aj konfirmácie z rokov 1457 a 1465. Nerozširujú síce práva a povinnosti poddaných, uvádzajú však mená žiadatel'ov. Platí to zvlášt' na Zvolenskom panstve, kde chýbajú početnejšie stredoveké doklady o menách obyvatel'ov jednotlivých dedín. Vzhl'adom na široké možnosti d'alšieho skúmania a interpretácie uverejňujeme podla platných transkripčných a edičných pravidiel listiny v prílohe v plnom znení.

\footnotetext{
30 Inzert v konfirmácii Maximiliána II. z roku 1573. MNL OL DL 24 339. Porov. TAGÁNYI, Károly (ed.): Magyar erdészeti oklevéltár I. Budapest : Pátria Irod. Vállalat Részvénytársaság Könyvnyomdája, 1896, s. 27 - 28, č. 94; ILLÉSSY, János: Községi kiváltságlevelek jegyzéke. Második közlemény. In: Magyar Gazdaságtörténelmi Szemle. 5. évf., 1898, s. 282; ZOLNAY, L.: Vadászatok a régi Magyarországon, s. 190, 195; CSŐRE, P.: A magyar erdőgazdálkodás története, s. 174; MAGYAR, E.: A királyi erdőkezelés kiváltságolt, s. 113 115; MALINIAK, P.: Človek a krajina, s. 182 - 183.
} 


\section{Prílohy}

Uhorský král' L'udovít I. z Anjou oslobodzuje král'ovských hájnikov z dedín Badín, Hájniky a Rybáre vo Zvolenskej stolici od platenia komorského zisku. Vyberačom komorského zisku prikazuje, aby ho od poddaných $v$ uvedených troch dedinách nevyberali.

Originál listiny sa nezachoval. Jej text z konfirmácie král’a Ladislava Pohrobka zo 7. apríla 1457, ktorej text sa zachoval v konfirmácii král'a Mateja Korvína z 24. marca 1465, ktorej text sa zachoval až v tranzumpte hronskobeňadického konventu z 22. júna 1543, uloženom v ÖStA, HHStA, Ungarische Akten, Allgemeine Akten, Fasc. 52 (1543. VI-IX.), Konv. A, fol. 50r-v.

Nos Ludovicus Dei gratia rex Hungarie memorie commendamus significantes tenore presentium, quibus expedit, universis, quod nos iobagionibus nostris, qui custodes silvarum nostrarum dicuntur in comitatu Zoliensi in tribus villis nostris, videlicet iuxta villam Badin, in Haynyk et in Halazekfalwa commorantibus gratiose annuimus, quod iidem iobagiones nostri exactiones seu solutiones pro lucro camere nostre solvere non teneantur. Vobis igitur universis lucri camere nostre exactoribus modernis et futuris firmiter precipiendo mandamus, quatenus nullas solutiones sive exactiones pro lucro ${ }^{a}$ camere nostre a predictis iobagionibus nostris petere vel recipere presumatis, quia eosdem iobagiones trium villarum, videlicet iuxta villam Badin $^{b}$ existentes, de Haynyk et de Halazekfalwa commisimus super premissis harum serie literarum perpetuo expeditos. Datum Zolii in festo Beati Jacobi Apostoli millesimo tricentesimo sexagesimo.

${ }^{a}$ Opravené z lucri. ${ }^{b}$ Opravené. $V$ zachovanom znení listiny de villa iuxta Badin. Na margu dopísané rovnakou rukou: villam.

Uhorský král' Žigmund Luxemburský na žiadost' poddaných z dedín Badín, Vel'ká Lúka, Rybáre, Hájniky, Kováčová, Tŕnie a Trebul'a potvrdzuje ich slobody, ktorými sa riadili počas vlády jeho predchodcu L'udovíta I. Kasteláni Zvolenského hradu poddaných zat’ažovali neprimeranými daňami, dávkami, službami a používaním väčšej miery. Žigmund určuje, aby každý 
Kolektívne práva a pvinností poddaných Zvolenského panstva ...

poddanský dvor odvádzal štyri vozy sena, štyri vozy dreva a obilie v takej miere, sakou sa obchoduje na tamojšom trhu. Dávky majú každoročne odvádzat' na miestach a v termínoch určených oddávna.

Originál listiny sa nezachoval. Jej text z konfirmácie král’a Ladislava Pohrobka zo 7. apríla 1457, ktorej text sa zachoval v konfirmácii krála Mateja Korvína z 24. marca 1465, ktorej text sa zachoval až v tranzumpte hronskobeňadického konventu z 22. júna 1543, uloženom v ÖStA, HHStA, Ungarische Akten, Allgemeine Akten, Fasc. 52 (1543. VI-IX.), Konv. A, fol. $50 v, 51 r-v$.

Nos Sigismundus Dei gratia rex Hungarie, Dalmatie, Croatie etc. marchioque Brandenburgensis etc. Sacri Romani Imperii vicarius generalis et regni Bohemie gubernator memorie commendamus per presentes, quod fideles cives et iobagiones nostri regales in possessionibus seu villis Badin, Velkeluka, Rybar, Haynyk, Kowacho, Thernye et Treble vocatis ad castrum nostrum regium Antiqui Zoliensem in comitatu Zoliensi habitum spectantibus commorantes ad nostre serenitatis accedentes conspectum humotenus ${ }^{a}$ provoluti, lamentabili cum querela nostre claritati, conquesti sunt in hunc modum, quod castellani sive vicecastellani in predicto castro nostro pro tempore constituti, census seu collectas nec non ligna, faena, avenam, blada et alia datia ac victualia et servitia de ipsorum medio prefatis nostris castellanis annuatim in dictis temporibus et locis ad hoc deputatis provenire solitos et administrari debentia, non prout iidem et eodem tempore quondam serenissimi principis foelicis reminiscentie domini Lodovici incliti regis, soceri nostri charissimi, exigebantur et administrabantur, sed tempus ante debitum in solutione et administratione eorundem tunc observari consuetum et cum maiori mensura non sine eorum incommodis et gravibus ad hec compulsionibus ${ }^{b}$ singulis annis tam superflue et incompassibiliter dicarent et exigerent, quod iidem ad extreme paupertatis inopiam et irrecuperabile detrimentum iam de facto attingentes ulterius nullo modo suffere valerent ${ }^{c}$ seu tollerare. Supplicantes exinde nostro culmini ${ }^{d}$ subiective et devote, ut ipsos ab huiusmodi dictorum castellanorum nostrorum oppressionibus exonerandos eos in eisdem antiquis libertatibus eorum et gratiarum prerogativis, quibus ipsi tempore dicti quondam Lodovici regis pacifice freti et gavisi fuissent, tenere et conservare facere dignaremur gratiose. Nos itaque querulosis supplicationibus, iustis et iuriconsonis prefatorum civium et iobagionum nostrorum favorabiliter exauditis ${ }^{e}$ ipsos per huiusmodi inconsuetas et superfluas dicationes, exactiones et administrationes dictorum censuum, victualium et servitiorum ulterius ${ }^{f}$ nullo modo opprimi, sed potius ut iidem sicuti immo sic et fideliter de cetero augeantur eosdem 
in premissis antiquis ipsorum libertatibus et gratiarum prerogativis, quibus ipsi tempore prefati quondam domini Lodovici regis usi fuere et gavisi illibate et pacifice conservare volentes. Decrevimus et presentis scripti nostri patrocinio inter alia stabilimus, ut singuli predictorum civium et iobagionum nostrorum in pretactis possessionibus commorantes de singulis fundis curiarum ipsorum in eisdem habitis et situatis, singulos quattuor currus foeni et totidem plaustra lignorum, preterea blada et avenam cum eadem mensura, qua eedem in foro publico ementur et venduntur, annuatim in locis et terminis ad hec antiquitus institutis prefatis nostris castellanis seu vicecastellanis seu officialibus eorundem more solito et non aliter dare et administrare teneantur. Ceterum sanximus, ut dicti castellani seu vicecastellani nostri predictos nostros fideles cives et iobagiones ad dictorum aut quorumcunque aliorum censuum, victualiorum et servitiorum ipsis de medio eorundem pervenire debent nullum terminum solutionis seu administrationis eorundem anticipando vel postergando, nequamque in aliis preterquam in locis et terminis ad hec deputatis astringere possint, seu coercere. Sanximus denique, ut ${ }^{g}$ sepefati nostri castellani seu vicecastellani super dictos nostros cives, iobagiones et populos nusquam alias dumtaxat, quando nostra maiestas partes suas Zolienses visitaturum attingeret, ${ }^{h}$ ad aliquorum victualium inconsuetorum seu superfluorum administrationem astringere presumant modo aliquali in aliis aut omnibus eisdem et singulis collectis, libertatibus et servitiis, quibus iidem tempore dicti quondam Lodovici regis quomodolibet de iure vel de consuetudine uti soliti fuerunt pacifice, irrefragabiliter ${ }^{i}$ et absque omni impedimento salvis eorum rebus et personis libere gaudeant et secure potiantur sub nostra protectione et tutela speciali harum nostrarum vigore et testimonio literarum mediante. Quocirca vel fidelibus nostris castellanis vel vicecastellanis sepedicti castri nostri Antiqui Zoliensi ac officialibus eorundem modernis scilicet et futuris, presentium notitiam habituris firmissime precipimus et omnino volentes mandamus, quatenus habitis presentibus a modoque temporibus perpetuo affuturis, prefatos fideles cives, populos et iobagiones nostros in dictis possessionibus pro tempore commorantes, pro quibus presentes exhibite fuerint in premissis specificatis et nominatis, nec non quibuslibet aliis et singulis eiusdem libertatibus, immunitatibus, laudabilibus, consuetudinibus et graciarum prerogativis in exactione et administratione collectarum, datiorum, victualium et servitiorum de ipsorum medio vobis provenire solita et debenda, quibus ipsi vivente prelibato quondam excellentissimo principe domino Lodovico rege, socero nostro charissimo usi fuere et gavisi, pacifice illese irrefragabiliter at absque aliquali impedimento tenere et conservare debeatis superflua et 
inconsueta datia, victualia aut servitia post decessum eiusdem quondam domini Lodovici regis ab ipsis hactenus peti et exigi solita, nullatenus ab eiusdem petere aut exigere presumendo, aliud sub obtentu nostrae gratie nullomodo facere audeatis in premissis, nec sitis ausi modo aliquali, presentes quoque post lecturam ${ }^{j}$ semper reddi iubemus presentanti. ${ }^{k}$ Datum in castro nostro Wegles Zoliensi in festo Ascensionis Domini anno eiusdem millesimo quadringentesimo decimo.

a Opravené $z$ unotenus. $b$ Opravené $z$ coinpulsionibus. $c$ Opravené $z$ valiture. ${ }^{d}$ Opravené $z$ talium. ${ }^{e}$ Opravené $z$ exaudire. $f$ V zachovanom znení napísané dvakrát za sebou ulterius. ${ }^{g}$ Opravené $z$ et. ${ }^{h}$ Opravené $z$ visitatur attingerit. ${ }^{i}$ Opravené $z$ irrefragiabiliter. ${ }^{j}$ Opravené $z$ per literas. ${ }^{k}$ Opravené $z$ presentati.

Budín, 7. apríla 1457

Uhorský král' Ladislav Pohrobok na žiadost' poddaných z dedín Rybáre a Hájniky, aj v mene ostatných poddaných z Badína, Vel'kej Lúky, Kováčovej, Tŕnia a Trebule vydáva konfirmáciu listín svojich predchodcov L'udovíta I. a Žigmunda. Obsah a ustanovenia obidvoch listín Ladislav Pohrobok v plnom rozsahu schvaluje a potvrdzuje.

Originál listiny sa nezachoval. Jej text z konfirmácie král’a Mateja Korvína $z$ 24. marca 1465, ktorej text sa zachoval v tranzumpte hronskobeňadického konventu z 22. júna 1543, uloženom v ÖStA, HHStA, Ungarische Akten, Allgemeine Akten, Fasc. 52 (1543. VI-IX.), Konv. A, fol. 49v, 50r, 51v, 52r.

Nos Ladislaus Dei gratia Hungarie, Bohemie, Dalmatie, Croatie etc. rex ac Austrie et Stirie dux, nec non marchio Morauie etc. memorie commendamus tenore presentium significantes, quibus expedit, universis, quod fideles nostri Bartholomeus Brazowyth in Halazekfalwa ac Georgius $^{a}$ Bober et Andreas filius eiusdem, iobagiones nostri in Haynyk possessionibus nostris commorantes nostre maiestatis venientes in presentiam in ipsorum ac universorum iobagionum nostrorum in eisdem ac Badyn, Velkelaka, Rybar, Kobacho, Tyrnie et Treple vocatis possessionibus nostris ad castrum Antiqui Zoliensem pertinentibus commorantium personis exhibuerunt et presentaverunt nobis quasdam duas literas excellentissimorum principum, unam quondam domini Ludovici super exemptione a solutione lucri camere, alteram per eundem dictis iobagionibus suis in pretactis possessionibus Halasecfalwa, Haynyk et Badin commorantibus facta et aliam quondam domini Sigismundi similiter huius regni nostri Hungarie etc. regum 
foelicium recordationum avi et predecessorum nostrorum charissimorum, quibus mediante idem quondam dominus Sigismundus rex id prefatis iobagionibus suis in dictis possessionibus Badin, Velekeluka, Rybar, Haynik, Cabacho, Thyrnye et Treble vocatis commorantibus, ut singuli predictorum iobagionum suorum in pretactis possessionibus commorantium de singulis fundis curiarum ipsorum in eisdem habitis singulos quattuor currus foeni et totidem plaustra lignorum, preterea blada et avenam cum eadem mensura, qua eedem in foro publico emebantur et vendebantur annuatim in locis et terminis ad haec antiquitus institutis castellanis prefati castri sui seu vicecastellanis aut officialibus eorundem more solito dare et administrare tenerentur statuisse ita, quod alia statuta eisdem iobagionibus suis sub dictis conditionibus clausulis et articulis inferius in tenore earundem literarum suarum manifestata fecisse dinoscitur ad relationem comitis Simonis de Rozgon, magistri curie sue, ambas in pergameno sigillis eorundem dominorum Ludovici et Sigismundi regum ratas, gratas et acceptas habendo literisque nostris privilegialibus verbotenus inseri et inscribi faciendo ipsis et prefatis universis iobagionibus nostris ipsorumque haeredibus et posteritatibus universis innovando perpetuo valituras confirmando ${ }^{b}$ dignaremur, quarum quidem literarum unius scilicet prefati quondam Ludovici regis tenor talis ${ }^{c}$ est: ${ }^{1}$ Alterius vero videlicet prefati quondam domini Sigismundi regis continentia verbalis hec est: ${ }^{2}$ Nos itaque humillimis et devotis supplicationibus prefatorum Bartholomei Prazowith, Georgii Bober et Andree filii eiusdem in ipsorum et aliorum, quorum supra nominibus et in personis per eos maiestati nostre premisso modo porrectis regia benignitate exauditis clementer et admissis prescriptas literas antefactorum quondam dominorum Ludovici et Sigismundi regum etc. non abrasas, non cancellatas, nec aliqua ipsarum parte suspectas, immo mere et sincere veritatis integritate prepollentes $^{d}$ de verbo ad verbum sine diminutione et augmento aliquali presentibus nostris literis privilegialibus inseri et inscribi faciendo, quoad omnes earundem continentias, clausulas et articulos acceptamus, approbamus et ratificamus, easque nihilominus mera regia authoritate et potestatis plenitudine ex certaque nostrae maiestatis scientia et animo deliberato de prelatorumque et baronum nostrorum consilio eatenus quatenus eedem rite et legitime existunt emanate et viribus earum veritas suffragatur pro prefatis Bartholomeo, Georgio et Andrea ac aliis iobagionibus in pretactis possessionibus nostris commorantibus ipsorumque heredibus et posteritatibus universis innovando perpetuo valituras confirmamus presentis scripti nostri patrocinio mediante iuribus nostris et aliorum semper salvis. In cuius rei memoriam firmitatemque perpetuam presentes concessimus literas nostras privilegiales penden- 
tis et autenticie secreti sigilli nostri, quo ut rex Hungarie utimur munimendo roboratas. Datum Bude feria quinta proxima ante dominicam Ramis Palmarum anno Domini millesimo quadringentesimo quinquagesimo septimo, regnorum autem nostrorum anno Hungarie etc. decimo septimo, Bohemie vero quarto.

${ }^{a}$ Opravené $z$ Gregorius. ${ }^{b}$ Opravené $z$ firmando. ${ }^{c}$ Opravené $z$ is. ${ }^{d}$ Opravené $z$ propellentes. ${ }^{e}$ Opravené $z$ attentici.

${ }^{1}$ Nasleduje znenie listiny vydanej L'udovítom I. z Anjou 25. júla 1360. Porov. listinu č. 1.

2 Nasleduje znenie listiny vydanej Žigmundom Luxemburským 1. mája 1410. Porov. listinu č. 2.

[Zvolen], 24. marca 1465

Uhorský král' Matej Korvín na žiadost' poddaných z dedín Badín a Rybáre, aj v mene ostatných poddaných z Hájnikov, Vel'kej Lúky, Kováčovej, Tŕnia a Trebule vydáva konfirmáciu listiny svojho predchodcu Ladislava Pohrobka. Obsah a ustanovenia listiny Matej Korvín v plnom rozsahu schval'uje a potvrdzuje.

Originál listiny sa nezachoval. Jej text z tranzumptu hronskobeňadického konventu z 22. júna 1543, uloženého v ÖStA, HHStA, Ungarische Akten, Allgemeine Akten, Fasc. 52 (1543. VI-IX.), Konv. A, fol. 49r-v, 52r-v, 53r.

Mathias Dei gracia Hungarie, Dalmatie, Croatie, Rame, Seruie, Gallicie, Lodomirie, Comanie, Bulgarieque rex omnibus Christi fidelibus presentibus pariter et futuris presentium notitiam habituris salutem in omnium salvatore. Ad universorum notitiam harum serie volumus pervenire, quod fideles nostri circumspecti Paulus Sember et Andreas Kernath in Badin ac Gregorius filius Mathei, nec non Bartholomeus Psar, iobagiones nostri in Halazfalwa possessionibus nostris commorantes, nostre maiestatis venientes in presentiam in ipsorum ac universorum iobagionum nostrorum in eisdem ac Haynyk, Velkeluka, Rybar, Kowacho, Thernie et Trebli vocatis possessionibus nostris ad castrum nostrum Antiqui Soliensem pertinentibus commorantium personis exhibuerunt nobis quasdam literas quondam serenissimi principis domini Ladislai similiter regis Hungarie etc. immediati predecessoris nostri sigillo suo secreto, quo ut rex Hungarie utebatur in pendenti consignatas tenores ${ }^{a}$ quarundam literarum quondam excellentissimorum principum dominorum Ludovici et Sigismundi similiter regum Hungarie etc. predecessorum nostrorum foelicium recordationum super rela- 
xacione lucri camere, nec non statutis et limitationibus censuum ipsorum sub certis conditionibus, clausulis et articulis inferius in tenoribus earundem literarum contentis confectarum et emanatarum confirmative in se continentem tenorum infrascriptorum, supplicantes maiestati nostre humiliter, ut easdem literas, ratas, gratas et acceptas habentes literisque nostris privilegialibus de verbo ad verbum inseri faciendo, approbando easque et omnia in eis contenta ipsis et eorum communitati innovando perpetuo valituras confirmare dignaremur. Quarum quidem literarum tenor talis est: ${ }^{1}$ Nos igitur humilibus supplicationibus annotatorum Pauli, Andree, Gregorii et Bartholomei per eos suis ac aliorum, quorum supra nominibus maiestati nostre porrectis regia benignitate exauditis et clementer admissis prefatas literas non abrasas, non cancellatas, nec in aliqua sui parte suspectas presentibusque literis nostris privilegialibus de verbo ad verbum sine diminutione et augmento aliquali insertas, quo ad omnes earum continentias, clausulas et articulos eatenus, quatenus eedem rite et legittime existunt emanate viribusque earum veritas suffragatur acceptamus, approbamus et ratificamus easque nihilominus et omnia in eis contenta pro prefatis populis et iobagionibus nostris et eorum communitati innovando perpetuo valituras confirmamus presentis scripti nostri patrocinio mediante, in cuius rei memoriam firmitatemque perpetuam presentes concessimus literas nostras privilegiales pendentis et autentici ${ }^{b}$ sigilli nostri duplicis munimine roboratas. Datum per manus reverendissimi in Christo patris domini Stephani ecclesiarum Colocensi et Bachiensi archiepiscopi locique eiusdem Colocensi comitis perpetui, aule nostre summi cancellarii fidelis nostri dilecti anno Domini millesimo quadringentesimo sexagesimo quinto, nono kalendas Aprilis regni nostri anno octavo, coronationis vero primo, venerabilibus in Christo patribus dominis eodem Stephano Colocensi archiepiscopo, Joanne episcopo ecclesie Waradiensi et postulato Strigoniensi, Ladislao Agriensi, Nicolao Transsyluaniensi, Zagrabiensi sede vacante, Joanne Quinqueecclesiensi, Albertho Wesprimiensi, Augustino Jauriensi, Vincentio Vaciensi, Albertho Chanadiensi, Thome Nytriensi, Boznensi sede vacante, Urbano Sirmiensi, Marco Tuminensi, ${ }^{c}$ Segniensi sede vacante, Nicolao Modrusiensi ecclesiarum episcopis, ecclesias Dei foeliciter gubernantibus, item magnificis Michaele Orzag de Gwth regni nostri Hungarie predicti palatino, Emerico de Zapolya regni Bozne gubernatore, Nicolao de Wylack et Joanne Pangracz de Dengeleg waywodis Transsyluanis, comite Ladislao de Palocz iudice curie nostre, eodem Emerico de Zapolya Dalmatie, Croatie et Sclauonie regnorum nostrorum et prefato Nicolao de Wylack Machoviensi banis honore banatus Zewriniensi vacante, Joanne de Rozgon thavernicorum, altero Joanne Thuz de Lak ianitorum, Nicolao de Al- 
solyndwa et Emerico de Palocz prefata pincernarum, Stephano de Peren et Ladislao de Bathor dapiferorum, Ladislao de Kanysa et Perthol$\mathrm{do}^{d}$ Ellerbach de Monyarokerek agazonum nostrorum regalium magistris, Andrea Paronikyrhar [Posoniensi] ${ }^{e}$ et Petro de Zakol Themesiensi [comitibus] ${ }^{f}$

${ }^{a}$ Opravené $z$ tenor. ${ }^{b}$ Opravené $z$ attentici. ${ }^{c}$ Tak $v$ zachovanom znení. V origináli zrejme Tininiensi. Ide o kninského biskupa Mareka. Porov. ŠA BB p. AZv, MMZv, Listiny, škat. 2, inv. č. 22. ${ }^{d}$ Nasleduje prečiarknuté de. ${ }^{e}$ $V$ zachovanom znení chýba označenie úradu, ktorý dopĺn̆am. V origináli zrejme Pawmkyrhar Posoniensi. Porov. ŠA BB p. AZv, MMZv, Listiny, škat. 2, inv. č. 22. Ide o bratislavského župana Ondreja Baumkirchera. ${ }^{f} \mathrm{~V} z a-$ chovanom znení chýba titul županov. DopÍñam comitibus.

${ }^{1}$ Nasleduje znenie listiny vydanej Ladislavom Pohrobkom 7. apríla 1457. Porov. listinu č. 3.

Hronský Beňadik, 22. júna 1543

Konvent $v$ Hronskom Beňadiku na žiadost' poddaných $z$ dedín Rybáre a Hájniky vydáva tranzumpt listiny uhorského král'a Mateja Korvína. Konvent potvrdzuje, že listina nie je poškodená, porušená, ani podozrivá a je prepísaná bez umenšenia alebo zväčšenia.

Jednoduchý odpis z roku 1543, na papieri, latinsky. Na poslednom fóliu poznámky mladšou rukou: atramentom „22 Jun.“ a ceruzou „1543“. ÖStA, HHStA, Ungarische Akten, Allgemeine Akten, Fasc. 52 (1543. VI-IX.), Konv. A, fol. $49 r, 53 r$.

Nos conventus ecclesie Sancti Benedicti de iuxta Gron memorie commendamus tenore presentium significantes, quibus expedit, universis, quod prudentes et circumspecti Georgius Raacz et Mathias Baal nominibus et in personis totius communitatis possessionum Halaz et Haynyk ad castrum Veteri Zoliensem spectantium et pertinentium commorantibus nostram personaliter veniens in presentiam exhibuerunt et presentaverunt auctas quasdam literas pie memorie serenissimi principis quondam domini Mathie regis Hungarie etc. privilegialiter sub sigillo eiusdem emanatas subinserendo, quod easdem literas propter locorum discrimina inopinate emergendo in spem cum ipsis deferre vel per homines suos ubique locorum iuxta necessitatis exigendo deferri facere non audeverit, petiverunt igitur nos iidem prefati $\mathrm{Ge}$ orgius Raacz et Mathias Baal modo premisso debita videlicet cum instancia, ut nos easdem literas transcribi et transummi facere ac paria 
earundem in transcripto literarum eisdem dare dignaremur iura eorum maiorem $\operatorname{ad}^{a}$ cautelam, quarum tenor talis est: ${ }^{1}$ Nos itaque iustis et condignis petitionibus prefatorum civium Georgii Raacz et Mathie Baal suorum et aliorum, quorum supra nominibus et in personis totius communitatis possessionum Halacz et Haynyk ad castrum Veteri Zoliensem spectantem et pertinentem commorantium per eos nobis porrectis favorabiliter inclinati easdem literas non abrasas, non cancellatas, nec in aliqua sui parte vitiatas aut suspectas, sed omni prorsus vitio suspitionis carens de verbo ad verbum sine diminutione et augmento aliquali transummi et transcribi ac presentibus literis nostris privilegialibus inseri faciendo paria earundem in transumpto presentium literarum nostrarum eisdem prefatis iuris ipsorum ad cautelam duximus concedendo. Datum ex praefato claustro abbatie Sancti Benedicti de iuxta Gron in festo Decem Millia Martirum anno Domini millesimo quingentesimo quadragesimo tertio.

a Nadpísané ad rovnakou rukou.

${ }^{1}$ Nasleduje znenie listiny vydanej Matejom Korvínom 24. marca 1465. Porov. listinu č. 4. 